\title{
Differences in GPR30 Regulation by Chlorotriazine Herbicides in Human Breast Cells
}

\author{
Colin P. Florian, Shelly R. Mansfield, and Jennifer R. Schroeder \\ Department of Biology, Millikin University, Decatur, IL 62522, USA \\ Correspondence should be addressed to Jennifer R. Schroeder; jrschroeder@millikin.edu
}

Received 16 July 2015; Revised 15 December 2015; Accepted 10 January 2016

Academic Editor: Bernardo Trigatti

Copyright (C) 2016 Colin P. Florian et al. This is an open access article distributed under the Creative Commons Attribution License, which permits unrestricted use, distribution, and reproduction in any medium, provided the original work is properly cited.

Over 200,000 cases of invasive breast cancer are diagnosed annually; herbicide contaminants in local water sources may contribute to the growth of these cancers. GPR30, a G protein coupled receptor, was identified as a potential orphan receptor that may interact with triazine herbicides such as atrazine, one of the most commonly utilized chlorotriazines in agricultural practices in the United States. Our goal was to identify whether chlorotriazines affected the expression of GPR30. Two breast cancer cell lines, MDAMB-231 and MCF-7, as well as one normal breast cell line, MCF-10A, were treated with a 100-fold range of atrazine, cyanazine, or simazine, with levels flanking the EPA safe level for each compound. Using real-time PCR, we assessed changes in GPR30 mRNA compared to a GAPDH control. Our results indicate that GPR30 expression increased in breast cancer cells at levels lower than the US EPA drinking water contamination limit. During this treatment, the viability of cells was unaltered. In contrast, treatment with chlorotriazines reduced the expression of GPR30 in noncancerous MCF-10A cells. Thus, our results indicate that cell milieu and potential to metastasize may play a role in the extent of GPR30 response to pesticide exposure.

\section{Introduction}

Over 1.1 billion pounds of pesticides is used annually in the USA, accounting for twenty-five percent of the total world usage [1]. These environmental chemicals may have dire consequences upon tissue development if brought in contact with several hormone-dependent tissues such as breast and ovarian, and this draws great concern as one in every eight American women is diagnosed with some form of breast cancer [2]. Triazine exposure has been highly correlated with the incidence of ovarian cancer [3]. Atrazine has also been known to cause mammary tumors in rats [4]. Cyanazine is considered moderately toxic showing decreased cell viability and maternal body weight and can cause depression [5]. Simazine is considered slightly nontoxic, although it is a reported mutagen in human lung cells, causes tumors in mammary and thyroid tissues in rats, and decreases birth weight while increasing fetotoxicity in rabbits $[6,7]$.

Through RT-PCR analysis, Albanito et al. [3] showed that estrogen-responsive genes that ultimately cause proliferation were upregulated in cancerous ovarian cell lines upon exposure to atrazine. More importantly, they showed that such genes were upregulated in cancerous breast cells that lack classical estrogen receptors $\mathrm{ER} \alpha$ and $\mathrm{ER} \beta$ [8], indicating a potential orphan receptor able to bind to atrazine and elicit intracellular changes. GPR30, a membrane-bound G protein coupled receptor, has been recognized as both a nonclassical receptor for estrogen and a potential receptor for triazines [9]; it is able to induce gene transcription through a variety of cellular pathways including increasing calcium and cAMP [10].

A study of GPR30 presence in MCF-7 cells shows receptor localization in the endoplasmic reticulum through fluorescently labelled estrogen derivatives [11]. Filardo et al. showed that the cancerous breast cell line MDA-MB-231 expressed low levels of GPR30 [12, 13]. Upregulation of estrogen dependent genes has been observed in these cells through the induction of MAP kinase pathways through GPR30 binding [14]. Cronan et al. [15] found that six of seven MAP3-kinases they tested regulated tumor growth and metastasis in MDA-MB-231 cells, suggestive of GPR30 presence [10]. Recent studies have indicated that although MCF-10A cells may lack or have very low levels of classical $\mathrm{ER}$, they do express and regulate gene expression through GPR30 [16, 17]. 
Rather than focusing upon estrogen-based activation of GPR30, in this study we have examined the potential to alter GPR30 gene expression through exposure to triazine class herbicides in two cancerous breast cell lines and one normal breast cell line. MCF-10A noncancerous and MCF-7 and MDA-MB-231 cancerous cell lines were treated with three different concentrations of atrazine, cyanazine, and simazine, flanking the levels considered safe in drinking water by the United States Environmental Protection Agency (EPA). Our hypothesis is that GPR30 expression will increase as the herbicides act as ligands for the receptor, thus upregulating its own expression. However, we expect to see discrete differences in the cell lines and expect that these differences may allow for clear separation between noncancerous cells and those with the ability to metastasize.

\section{Materials and Methods}

2.1. Cell Culture and Maintenance. All cell lines were obtained from the lab of Dr. Ann Nardulli (University of Illinois at Urbana-Champaign, Urbana, IL), subcultured from stocks originally obtained from ATCC (Manassas, VA). MDAMB-231 human epithelial adenocarcinoma cells were maintained in DMEM/F-12 media supplemented with $10 \%$ fetal calf serum and antibiotics (50 IU/mL penicillin, $50 \mu \mathrm{g} / \mathrm{mL}$ streptomycin, and $5 \mu \mathrm{g} / \mathrm{mL}$ gentamycin sulfate) at $37^{\circ} \mathrm{C}$ in a humidified, 5\% $\mathrm{CO}_{2}$ environment. MCF-7 human epithelial adenocarcinoma cells were maintained in Modified Eagle's Media supplemented with $5 \%$ calf serum and antibiotics, while assays were performed in either maintenance media or reduced medium containing phenol red-free Modified Eagle's Media and supplemented with 5\% charcoal dextran-stripped calf serum and antibiotics. MCF-10A cells were maintained in DMEM/F-12 media supplemented with 5\% horse serum, MEGS supplement, and $0.1 \mu \mathrm{g} / \mathrm{mL}$ cholera toxin.

2.2. Cell Viability. MCF-7 and MDA-MB-231 cells were seeded into 96-well plates either in maintenance media (MCF-7 and MDA-MB-231) or in reduced media (MCF-7). Twenty-four hours after plating, the media were replaced with maintenance (MCF-7 and MDA-MB-231) or reduced (MCF-7) media containing atrazine, simazine, or cyanazine at 0.1-, 1-, and 10-fold the EPA safe levels (Table 1) or DMSO control. Atrazine was added at $0.3,3.0$, or $30 \mathrm{ppb}(\mu \mathrm{g} / \mathrm{L}$; $0.64-64 \mu \mathrm{M})$, cyanazine was added at $0.1,1.0$, or $10 \mathrm{ppb}$ $(0.17-17 \mu \mathrm{M})$, and simazine was added at $0.4,4.0$, or $40 \mathrm{ppb}$ $(0.92-92 \mu \mathrm{M})$. After twenty-four hours, $3 \mu \mathrm{g}$ resazurin was added and allowed to incubate for three hours prior to reading absorbance at 570 and $595 \mathrm{~nm}$ on iMark Microplate Absorbance Reader (Bio-Rad, Hercules, CA). We performed univariate analysis of variance (ANOVA) using SPSS (IBM SPSS Statistics, IBM Corp., Armonk, NY).

2.3. GPR30 Expression Analysis. Prior to treatment, cells were seeded into 12 -well plates in their respective maintenance media. Twenty-four hours after plating, the media were replaced with maintenance media containing atrazine, simazine, or cyanazine at 0.1-, 1-, and 10-fold the EPA safe levels (Table 1), or DMSO control. After twenty-four hours,
TABle 1: Pesticide use levels based upon US EPA maximum contamination levels (MCL) for drinking water. Modified from Rich et al. [18].

\begin{tabular}{lcccc}
\hline & MCL $(\mu \mathrm{g} / \mathrm{L})$ & $0.1 \mathrm{x}(\mu \mathrm{g} / \mathrm{L})$ & $1 \mathrm{x}(\mu \mathrm{g} / \mathrm{L})$ & $10 \mathrm{x}(\mu \mathrm{g} / \mathrm{L})$ \\
\hline Atrazine & 3 & 0.3 & 3 & 30 \\
Cyanazine & 1 & 0.1 & 1 & 10 \\
Simazine & 4 & 0.4 & 4 & 40 \\
\hline
\end{tabular}

RNA was harvested using RNAzol (Molecular Research Center, Inc., Cincinnati, OH) per manufacturer's recommendations. Extracted nucleotides were treated with DNase, and cDNA was synthesized using RT-PCR with random primers using GoScript Reverse Transcriptase (Promega, Madison, WI) according to manufacturer's recommendations.

Real-time PCR was run in triplicate for 40 cycles using a Bio-Rad iCycler iQ (Bio-Rad, Hercules, CA). GAPDH was used as a reference gene. GAPDH (ReadyMade Primer Sequence, IDT DNA Technologies, Coralville, IA) and GPR30 primers [19] for real-time PCR were obtained from IDT DNA Technologies (Coralville, IA) with the following sequences:

\section{GAPDH forward: $5^{\prime}$-ACCACAGTCCATGCCATC- AC-3', \\ GAPDH reverse: $5^{\prime}$-TCCACCACCCTGTTGCTG- TA-3', GPR30 forward: 5' -AGTCGGATGTGAGGTTCAG- $3^{\prime}$, \\ GPR30 reverse: $5^{\prime}$-TCTGTGTGAGGAGTGCAAG- $3^{\prime}$.}

The $\Delta \mathrm{Ct}$ value was calculated by subtracting the control gene amplification cycle from the GPR30 amplification cycle within each treatment. To calculate $\Delta \Delta \mathrm{Ct}, \Delta \mathrm{Ct}$ value for the control treatment (DMSO) was subtracted from each experimental treatment. Fold change was calculated using $2 \Delta \Delta \mathrm{Ct}[20]$. We performed univariate analysis of variance (ANOVA) using SPSS (IBM SPSS Statistics, IBM Corp., Armonk, NY).

\section{Results}

To ensure that treatment with pesticides did not cause dramatic changes in cell viability, we treated MCF-7 breast cancer cells with three concentrations of atrazine, cyanazine, or simazine. Concentrations selected flanked the maximum contamination levels for drinking water set by the US EPA (Table 1).

Cell viability was measured using resazurin, which is reduced to resorufin in the presence of metabolically active cells [21]. We maintained MCF-7 cells in a reduced medium to eliminate hormonal effects and treated them with atrazine, cyanazine, or simazine at 0.1-, 1-, or 10-fold the EPA safe level in drinking water for twenty-four hours. We observed no statistically different changes in cell viability in the presence of atrazine or cyanazine and only a small difference when comparing 0.1x simazine to the DMSO control (Figure 1(a)). 


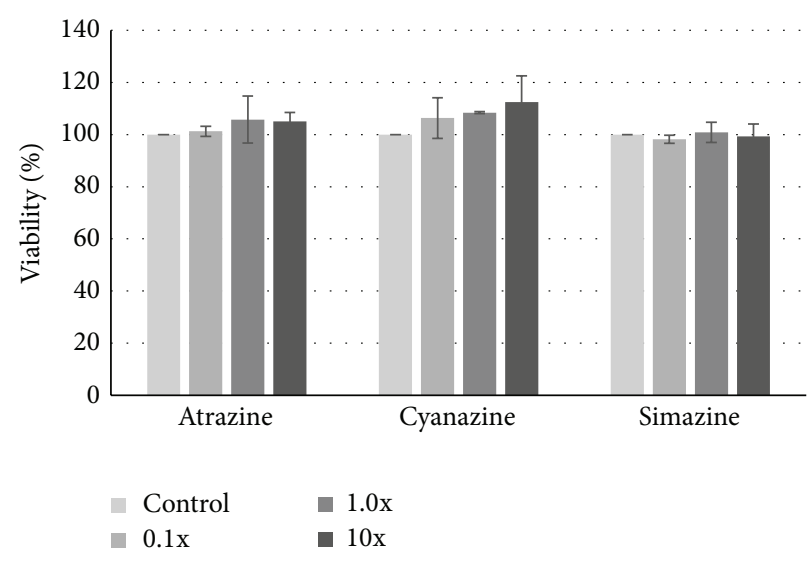

(a)

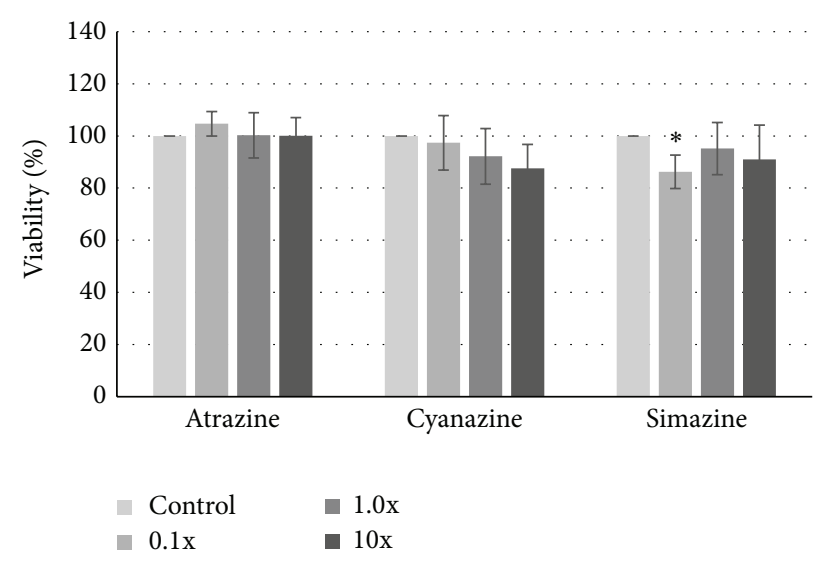

(b)

FIGURE 1: Cell viability of MCF-7 cells treated with triazine herbicides. MCF-7 human breast cancer cells were treated with 0.1- to 10-fold concentrations of the EPA safe levels of atrazine, cyanazine, or simazine for 24 hours in reduced (a) or maintenance (b) media. Cell viability was determined by levels of reduction of resazurin to resorufin by metabolically active cells. Percent viability of cells \pm standard deviation is shown, with the DMSO-treated controls normalized to 100 percent. Statistically significant changes in viability compared to the vehicle control are indicated $\left({ }^{*} p<0.05\right)$.

As minimal media can induce cellular stress, we repeated the viability assay using MEM with calf serum. As with the reduced medium, we noted no statistical difference in viability at any concentration of any of the three triazines (Figure 1(b)). Thus, we proceeded with the richer maintenance medium for the remainder of our study.

To assess the ability of chlorotriazines to induce changes in GPR30 mRNA expression, we then treated MCF-7 cells with the same three concentrations of atrazine, cyanazine, and simazine. mRNA was harvested and utilized to synthesize cDNA, which was then selectively amplified using primers specific to GPR30 using previously published primers by Girgert et al. [19] or a genomic control, GAPDH. As a housekeeping gene, GAPDH levels should not fluctuate upon treatment with the pesticides.

Treatment with atrazine resulted in a change in the expression of GPR30. At the lowest concentration, we observed a modest 1.8-fold increase compared to treatment with the DMSO control, and at the EPA safe level the increase was 2.7-fold (Figure 2). However, at the highest concentration, levels fell to the untreated levels. Although we were unable to identify any statistically significant changes for cyanazine, a trend of increase was observed, with 23 -fold increases in expression at all three concentrations. While not statistically significant, the 3.1-fold increase at $0.1 \mathrm{x}$ approached significance $(p=0.054)$. Treatment with simazine had no effect at low levels; however GPR30 expression was statistically higher at the $10 \mathrm{x}$ concentration (2.0-fold increase).

To identify whether these changes were a property of treating cancerous cells with triazines, we analysed GPR30 expression in another breast cancer cell line, MDA-MB-231, as well as the noncancerous MCF-10A cell line. As observed in Figure 3, treatment of MDA-MB-231 cells with pesticides also resulted in modest, 1.5- to 2-fold increases in GPR30 expression, although the patterns differed slightly from those observed in MCF-7 cells. We detected statistically significant

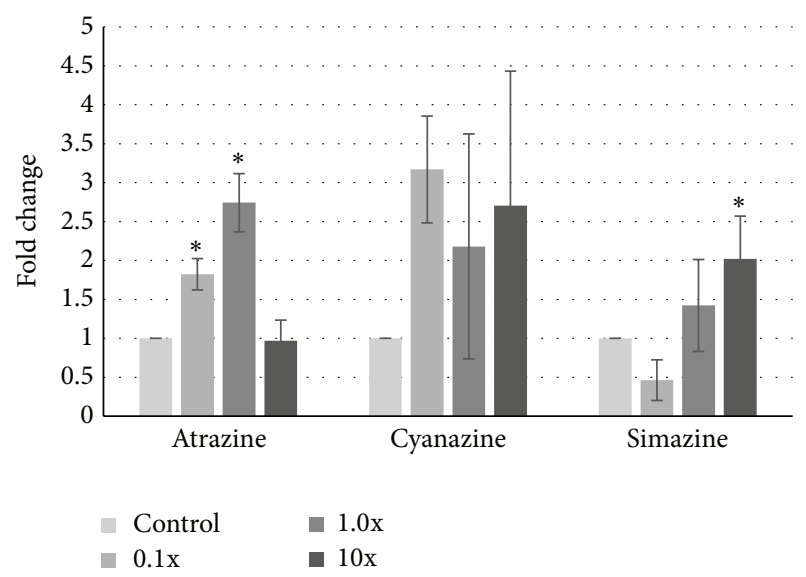

FIGURE 2: Increases in GPR30 expression in MCF-7 cells after atrazine exposure. MCF-7 human breast cancer cells were treated with 0.1 - to 10-fold concentrations of the EPA safe levels of atrazine, cyanazine, or simazine for 24 hours. mRNA was harvested, cDNA was synthesized, and specific amplicons were prepared using primers to GAPDH (reference gene) or GPR30. Resulting fold changes in expression \pm standard deviation are shown, with the vehicle control set at 1 . Statistically significant changes in induction compared to the control are indicated $\left({ }^{*} p<0.05\right)$.

increases in GPR30 expression at the EPA safe level of atrazine, but not at concentrations above or below that level. In contrast, increases were observed at the lowest concentration of cyanazine, and trends for increases were seen for both $1 \mathrm{x}$ and $10 \mathrm{x}$ concentrations, with the $10 \mathrm{x}$ approaching significance $(p=0.08)$. For simazine, increases were observed at the $0.1 \mathrm{x}$ concentration, while the $1 \mathrm{x}$ concentration resulted in statistically lowered levels of GPR30.

We identified the most striking difference, however, in the noncancerous MCF-10A cells. In contrast to the cancerous cells, we detected significant decreases in GPR30 expression 


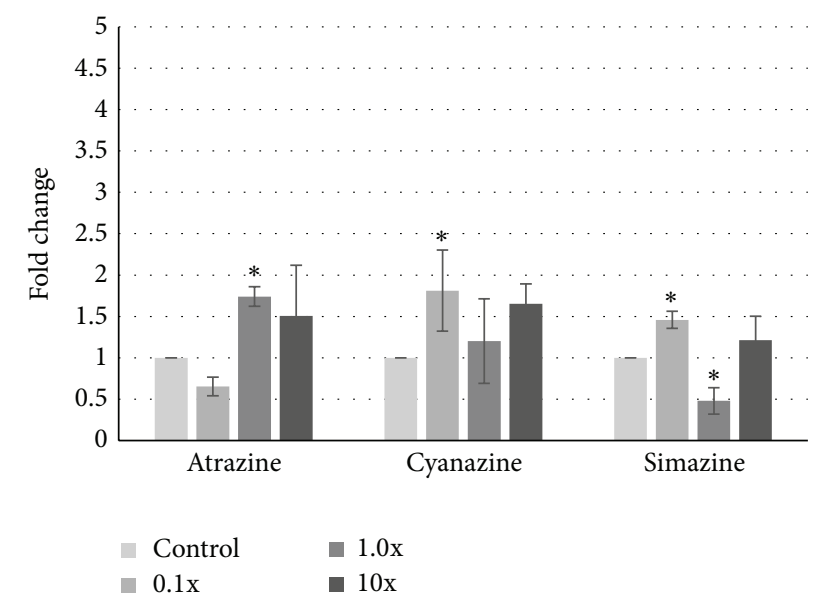

FIgURE 3: Change in GPR30 expression in MDA-MB-231 cells after atrazine exposure. MDA-MB-231 human breast cancer cells were treated with 0.1- to 10-fold concentrations of the EPA safe levels of atrazine, cyanazine, or simazine for 24 hours. mRNA was harvested, cDNA was synthesized, and specific amplicons were prepared using primers to GAPDH (reference gene) or GPR30. Resulting fold changes in expression \pm standard deviation are shown, with the vehicle control set at 1 . Statistically significant changes in induction compared to the control are indicated $\left({ }^{*} p<0.05\right)$.

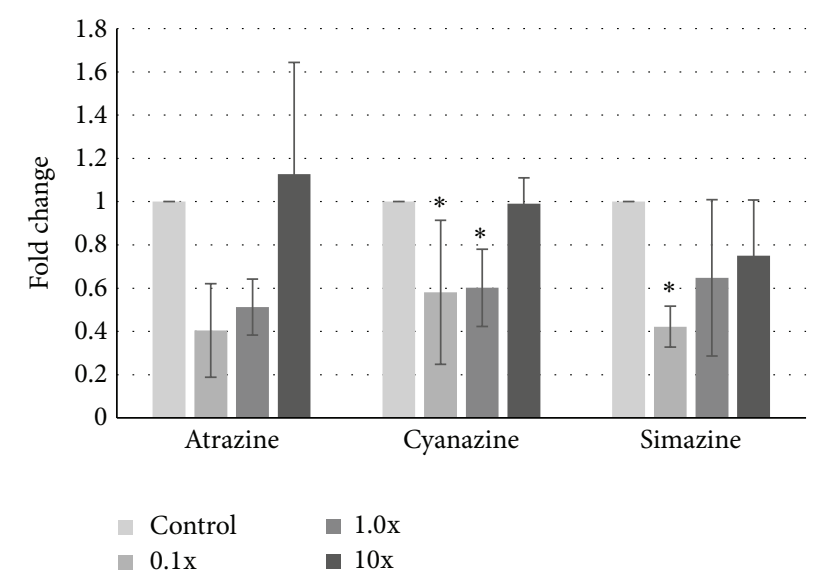

FIgURE 4: Change in GPR30 expression in MCF-10A cells after atrazine exposure. MCF-10A noncancerous breast cells were treated with 0.1- to 10-fold concentrations of the EPA safe levels of atrazine, cyanazine, or simazine for 24 hours. mRNA was harvested, cDNA was synthesized, and specific amplicons were prepared using primers to GAPDH (reference gene) or GPR30. Resulting fold changes in expression \pm standard deviation are shown, with the vehicle control set at 1 . Statistically significant changes in induction compared to the control are indicated $\left({ }^{*} p<0.05\right)$.

(Figure 4). For atrazine, a trend of decreased expression was seen, with levels below 0.5 -fold expression which was nearly statistically significant $(p=0.064$ and 0.084 for $0.1 \mathrm{x}$ and $1 \mathrm{x}$ concentrations, resp.). Cyanazine exposure also led to a reduction in GPR30 expression at both $0.1 \mathrm{x}$ and $1 \mathrm{x}$ concentrations. Simazine treatment significantly reduced GPR30 expression to 0.6 -fold only at the lowest concentration, although the higher concentrations showed indication of reduced expression as well.

\section{Discussion}

GPR30 has been identified in a variety of tissues, many of which are $\mathrm{ER} \alpha$-positive, as reviewed in $[10,22]$. There has been conflicting evidence regarding the ability of GPR30 to interact with $17 \beta$-estradiol; although there are several reports of altered gene expression through the interaction of estrogens to GPR30 [23, 24], others report a failure of atrazine to bind $[25,26]$. Others report that much higher levels of estrogens and antiestrogens must be utilized to illicit a response [27]. Conversely, ER directly regulates GPR30 expression in MCF-7 cells [28, 29].

We were initially concerned that the rich medium used in our preliminary studies might influence gene expression, due to the reports of GPR30 being able to substitute for the estrogen receptor to drive gene expression $[12,28,30]$, and that the phenol red in our medium might also trigger a response [31]. However, more recent studies have confirmed that the amount of phenol red in current maintenance media is not high enough to stimulate estrogen-responsive gene expression [32]. The lack of difference between treated cell growth in MCF-7 cells kept in a reduced medium (hormonefree and lacking phenol red) and our maintenance medium (containing serum and phenol red) indicates that the assays being performed are not dependent upon any estrogenicity of the triazines (Figure 1). This is in agreement with our previous work which examined the viability of MCF-7 and MDA-MB231 cells after treatment with four herbicides at levels just above those deemed safe for daily consumption by the US EPA [18]. Our current study examines levels that overlap this work, yet it looks at a shorter treatment time (twentyfour instead of forty-eight hours). If atrazine, cyanazine, and simazine were to be working through estrogenic pathways in our study, we would have expected an increase in cell viability even at twenty-four hours of treatment, especially within cells carried in a reduced medium $[33,34]$. In fact, recent work by de la Casa-Resino and Albanito has confirmed early studies by Connor et al. that chlorotriazine compounds do not bind to nor activate gene expression directly through the classical estrogen receptor [35-37]. This, combined with previous reports of altered growth and cellular responses when MCF7 cells are in a deprived medium $[38,39]$, supports our going forward with our studies in a richer medium that promoted a more robust growth of cells.

Although the levels of triazine class herbicides used in this and our previous work did not alter cell growth, nor did it affect cellular migration $[18,40]$, we wanted to determine if genomic changes in GPR30 occurred with chlorotriazine exposure. In fact, upon examining the expression level of GPR30, the proposed receptor for these compounds, we did observe discrete differences in expression dependent upon cell milieu. While levels of GPR30 were reduced in the noncancerous MCF-10A cells when exposed to low levels of atrazine, cyanazine, and simazine (Figure 4), we saw striking differences in the cancerous cell lines. In both MDA-MB-231 and MCF-7 cells, we observed an increase, albeit modest, in GPR30 expression at these same concentrations (Figures 2 and 3). Interestingly, it has been proposed that one role of GPR30 is to antagonize growth of ER $\alpha$-positive breast cancer 
cells, such as the MCF-7 cell line, yet support growth of ERnegative tumors $[28,41]$. This may be through the ability of GPR30 to limit ER activity [42].

Despite the alteration in GPR30 expression upon triazine treatment, we would be remiss to associate these changes solely with the possible interaction of these pesticides with GPR30 alone. Albanito et al. have shown that atrazine is able to bind directly to GPR30 to activate Erk phosphorylation and gene expression $[3,36]$. However, the altered expression of GPR30 in our study may or may not be due to direct interaction of these compounds with GPR30 itself. GPR30 can be upregulated through several ligands such as EGF, IGF-1, and VEGF $[29,43,44]$ and may be activated by progesterone as well $[45,46]$. GPR30 has also been shown to activate the c-Fos/AP1 pathway, and these trans-acting factors in turn upregulate GPR30 [30, 47-49].

We believe that it is possible that the differences we observe in GPR30 regulation by triazines may be indicative of a cell's metastatic state. The ability of atrazine in particular to cause a change in gene regulation is also consistent with the previously observed ability of xenoestrogens, especially chlorotriazines [24,50], although the roles of cyanazine and simazine have been less well studied than atrazine. Our previous studies did not indicate changes in growth rates when we utilized atrazine, cyanazine, and simazine at levels that far exceeded the EPA safe level in drinking water [18]. Likewise, when assessing the ability to respond after artificial wound induction, MCF-7 cells showed no change from the DMSO control when exposed to triazines, with less than $40 \%$ regrowth over 72 hours [40]; this was in contrast to the effects of estradiol which stimulated regrowth and migration. MDA-MB-231 cells exhibited initial regrowth at a rate below the control, while MCF-10A cells were fully regrown in that same timespan regardless of treatment used (hormonal or pesticide). This data correlates well with examination of primary tumors, where GPR30 overexpression is observed in high-grade and aggressive breast and ovarian cancers [27, 5153]. Activation of GPR30 triggers an intracellular signalling cascade, leading to increased levels of cAMP and activated protein kinase A [23, 24, 54], as well as activation of Erk [8]. In several studies, it has been shown that the activation of Erk leads to a transfer from the G1 to $S$ phase, thus leading to cell division $[55,56]$. These pathway activations may allow for the progression of breast cancer [57-59], and this has been directly suggested by Vivacqua et al. [44] with overexpression of GPR30 in the development of aggressive phenotypes in estrogen-dependent breast cancers.

Taking those results in context with our current study, we see that a downregulation of GPR30 after triazine exposure in MCF-10A may be protective, correlating with normal growth patterns and an inability to respond to further pesticide exposure through the cAMP pathway. This is a pathway often utilized by steroid hormones, where the compounds downregulate their own receptors [60-63] to limit cellular responses. However, metastatic cells, through upregulation of GPR30, see a shift in the ability of the cells to regrow. We may expect that the upregulation of GPR30 allows for the cAMPinduced "brake" to be placed on the Erk pathway, thus forcing cells to rely upon induction of MAP kinase pathways for further growth [14]. Thus, while there are conflicting reports as to the toxicity of chlorotriazine herbicides [4], the potential for damage may depend upon the existing cell milieu.

\section{Conclusion}

Treatment with triazines did not alter cell viability in MCF-7 cells; however, we observed upregulation of GPR30 mRNA. This pattern of upregulation was also seen in the cancerous MDA-MB-231 cells but not in the noncancerous breast cell line MCF-10A. Thus, the metastatic potential of a cell line may play a role in the ability of cells to regulate the amount of GPR30 transcript produced when cells are exposed to an environmental ligand.

\section{Conflict of Interests}

The authors declare that there is no conflict of interests regarding the publication of this paper.

\section{Acknowledgments}

The authors thank Dr. Ann M. Nardulli and Ms. Yvonne S. Ziegler (UIUC) for the breast cell lines and culture advice, Dr. Travis Wilcoxen (MU) for statistical advice, and Mr. James Mangis for technical support. This research was supported the Millikin University Howard L. Gravett Endowed Chair (to Jennifer R. Schroeder), the Brohard Cancer Research Fund, and the Millikin University Department of Biology.

\section{References}

[1] M. C. R. Alavanja, M. K. Ross, and M. R. Bonner, "Increased cancer burden among pesticide applicators and others due to pesticide exposure," CA: A Cancer Journal for Clinicians, vol. 63, no. 2, pp. 120-142, 2013.

[2] R. Ferro, A. Parvathaneni, S. Patel, and P. Cheriyath, "Pesticides and breast cancer," Advances in Breast Cancer Research, vol. 1, no. 3, pp. 30-35, 2012.

[3] L. Albanito, R. Lappano, A. Madeo et al., "G-Protein-coupled receptor 30 and estrogen receptor- $\alpha$ are involved in the proliferative effects induced by atrazine in ovarian cancer cells," Environmental Health Perspectives, vol. 116, no. 12, pp. 16481655, 2008.

[4] W. J. Hayes and E. R. Laws, Handbook of Pesticide Toxicology, Academic Press, San Diego, Calif, USA, 1991.

[5] U. S. E. P. Agency, Health Advisory Summary: Cyanazine, Office of Drinking Water, U.S. Environmental Protection Agency, Washington, DC, USA, 1988.

[6] A. M. Fan and G. V. Alexeeff, Public Health Goal for Simazine in Drinking Water, vol. 40, CEPA Office of Environmental Health Hazard Assessment, 2001.

[7] M. Silva and P. Iyer, "Toxicity endpoint selections for a simazine risk assessment," Birth Defects Research Part B: Developmental and Reproductive Toxicology, vol. 101, no. 4, pp. 308-324, 2014.

[8] L. Albanito, A. Madeo, R. Lappano et al., "G protein-coupled receptor 30 (GPR30) mediates gene expression changes and growth response to $17 \beta$-estradiol and selective GPR30 ligand G-1 in ovarian cancer cells," Cancer Research, vol. 67, no. 4, pp. 1859-1866, 2007. 
[9] S. Chakrabarti and S. T. Davidge, "G-protein coupled receptor 30 (GPR30): a novel regulator of endothelial inflammation," PLoS ONE, vol. 7, no. 12, Article ID e52357, 2012.

[10] M. Maggiolini and D. Picard, "The unfolding stories of GPR30, a new membrane-bound estrogen receptor," Journal of Endocrinology, vol. 204, no. 2, pp. 105-114, 2010.

[11] C. M. Revankar, H. D. Mitchell, A. S. Field et al., "Synthetic estrogen derivatives demonstrate the functionality of intracellular GPR30," ACS Chemical Biology, vol. 2, no. 8, pp. 536-544, 2007.

[12] E. J. Filardo, J. A. Quinn, A. Raymond Frackelton Jr., and K. I. Bland, "Estrogen action via the G protein-coupled receptor, GPR30: stimulation of adenylyl cyclase and cAMP-mediated attenuation of the epidermal growth factor receptor-to-MAPK signaling axis," Molecular Endocrinology, vol. 16, no. 1, pp. 7084, 2002.

[13] R. Girgert, G. Emons, and C. Gründker, "Inhibition of GPR30 by estriol prevents growth stimulation of triple-negative breast cancer cells by 17 $\beta$-estradiol," BMC Cancer, vol. 14, p. 935, 2014.

[14] A. Vivacqua, E. Romeo, P. De Marco, E. M. De Francesco, S. Abonante, and M. Maggiolini, "GPER mediates the Egr-1 expression induced by 17beta-estradiol and 4-hydroxitamoxifen in breast and endometrial cancer cells," Breast Cancer Research and Treatment, vol. 133, no. 3, pp. 1025-1035, 2012.

[15] M. R. Cronan, K. Nakamura, N. L. Johnson et al., "Defining MAP3 kinases required for MDA-MB-231 cell tumor growth and metastasis," Oncogene, vol. 31, no. 34, pp. 3889-3900, 2012.

[16] A. L. Scaling, E. R. Prossnitz, and H. J. Hathaway, "Gper mediates estrogen-induced signaling and proliferation in human breast epithelial cells and normal and malignant breast," Hormones and Cancer, vol. 5, no. 3, pp. 146-160, 2014.

[17] A. M. Wróbel and E. Ł. Gregoraszczuk, "Action of methyl-, propyl- and butylparaben on GPR30 gene and protein expression, cAMP levels and activation of ERK1/2 and PI3K/Akt signaling pathways in MCF-7 breast cancer cells and MCF-10A non-transformed breast epithelial cells," Toxicology Letters, vol. 238, no. 2, pp. 110-116, 2015.

[18] J. D. Rich, S. M. Gabriel, and J. R. Schultz-Norton, "In vitro effects of herbicides and insecticides on human breast cells," ISRN Toxicology, vol. 2012, Article ID 232461, 9 pages, 2012.

[19] R. Girgert, G. Emons, and C. Gründker, "Inactivation of GPR30 reduces growth of triple-negative breast cancer cells: possible application in targeted therapy," Breast Cancer Research and Treatment, vol. 134, no. 1, pp. 199-205, 2012.

[20] K. J. Livak and T. D. Schmittgen, "Analysis of relative gene expression data using real-time quantitative pcr and the $2^{-\Delta \Delta C_{T}}$ method," Methods, vol. 25, no. 4, pp. 402-408, 2001.

[21] J. O'Brien, I. Wilson, T. Orton, and F. Pognan, "Investigation of the alamar blue (resazurin) fluorescent dye for the assessment of mammalian cell cytotoxicity," European Journal of Biochemistry, vol. 267, no. 17, pp. 5421-5426, 2000.

[22] C. Carmeci, D. A. Thompson, H. Z. Ring, U. Francke, and R. J. Weigel, "Identification of a gene (GPR30) with homology to the G-protein-coupled receptor superfamily associated with estrogen receptor expression in breast cancer," Genomics, vol. 45, no. 3, pp. 607-617, 1997.

[23] C. M. Revankar, D. F. Cimino, L. A. Sklar, J. B. Arterburn, and E. R. Prossnitz, "A transmembrane intracellular estrogen receptor mediates rapid cell signaling," Science, vol. 307, no. 5715, pp. 1625-1630, 2005.

[24] P. Thomas, Y. Pang, E. J. Filardo, and J. Dong, "Identity of an estrogen membrane receptor coupled to a $G$ protein in human breast cancer cells," Endocrinology, vol. 146, no. 2, pp. 624-632, 2005.

[25] G. Langer, B. Bader, L. Meoli et al., "A critical review of fundamental controversies in the field of GPR30 research," Steroids, vol. 75, no. 8-9, pp. 603-610, 2010.

[26] E. R. Levin, "Minireview: extranuclear steroid receptors: roles in modulation of cell functions," Molecular Endocrinology, vol. 25, no. 3, pp. 377-384, 2011.

[27] D. P. Pandey, R. Lappano, L. Albanito, A. Madeo, M. Maggiolini, and D. Picard, "Estrogenic GPR30 signalling induces proliferation and migration of breast cancer cells through CTGF," The EMBO Journal, vol. 28, no. 5, pp. 523-532, 2009.

[28] E. A. Ariazi, E. Brailoiu, S. Yerrum et al., "The G protein-coupled receptor GPR30 inhibits proliferation of estrogen receptorpositive breast cancer cells," Cancer Research, vol. 70, no. 3, pp. 1184-1194, 2010.

[29] L. Albanito, D. Sisci, S. Aquila et al., "Epidermal growth factor induces $\mathrm{G}$ protein-coupled receptor 30 expression in estrogen receptor-negative breast cancer cells," Endocrinology, vol. 149, no. 8, pp. 3799-3808, 2008.

[30] M. Maggiolini, A. Vivacqua, G. Fasanella et al., "The G proteincoupled receptor GPR30 mediates c-fos up-regulation by $17 \beta$ estradiol and phytoestrogens in breast cancer cells," The Journal of Biological Chemistry, vol. 279, no. 26, pp. 27008-27016, 2004.

[31] Y. Berthois, J. A. Katzenellenbogen, and B. S. Katzenellenbogen, "Phenol red in tissue culture media is a weak estrogen: implications concerning the study of estrogen-responsive cells in culture," Proceedings of the National Academy of Sciences of the United States of America, vol. 83, no. 8, pp. 2496-2500, 1986.

[32] J. E. Moreno-Cuevas and D. A. Sirbasku, "Estrogen mitogenic action. III. Is phenol red a 'red herring??" In Vitro Cellular and Developmental Biology-Animal, vol. 36, no. 7, pp. 447-464, 2000.

[33] C. F. Holinka, Y. Anzai, H. Hata, N. Kimmel, H. Kuramoto, and E. Gurpide, "Proliferation and responsiveness to estrogen of human endometrial cancer cells under serum-free culture conditions," Cancer Research, vol. 49, no. 12, pp. 3297-3301, 1989.

[34] T. E. Wiese, L. G. Kral, K. E. Dennis, W. B. Butler, and S. C. Brooks, "Optimization of estrogen growth response in MCF-7 cells," In Vitro Cellular and Developmental Biology, vol. 28, no. 9-10, pp. 595-602, 1992.

[35] K. Connor, J. Howell, I. Chen et al., "Failure of Chloro$\mathrm{S}$-triazine-derived compounds to induce estrogen receptormediated responses in vivo and in vitro," Toxicological Sciences, vol. 30, no. 1, pp. 93-101, 1996.

[36] L. Albanito, R. Lappano, A. Madeo et al., "Effects of atrazine on estrogen receptor alpha- and g protein-coupled receptor 30mediated signaling and proliferation in cancer cells and cancerassociated fibroblasts," Environmental Health Perspectives, vol. 123, pp. 493-499, 2015.

[37] I. de la Casa-Resino, J. M. Navas, and M. L. Fernández-Cruz, "Chlorotriazines do not activate the aryl hydrocarbon receptor, the oestrogen receptor or the thyroid receptor in in vitro assays," Alternatives to Laboratory Animals, vol. 42, no. 1, pp. 25-30, 2014.

[38] P. D. Darbre, "Hypersensitivity and growth adaptation of oestrogen-deprived MCF-7 human breast cancer cells," Anticancer Research, vol. 34, no. 1, pp. 99-105, 2014.

[39] P. A. Jones, V. A. Baker, A. Irwin, and L. K. Earl, "Modulation of MCF-7 cell proliferative responses by manipulation of assay conditions," Toxicology in Vitro, vol. 11, no. 6, pp. 769-773, 1997. 
[40] A. M. Jesionowski, S. M. Gabriel, J. D. Rich, and J. R. Schroeder, "Failure of pesticides to alter migration of cancerous and noncancerous breast cell lines in vitro," Toxicology Research, vol. 4, no. 1, pp. 99-105, 2015.

[41] H.-J. Luo, P. Luo, G.-L. Yang, Q.-L. Peng, M.-R. Liu, and G. Tu, "G-protein coupled estrogen receptor 1 expression in primary breast cancers and its correlation with clinicopathological variables," Journal of Breast Cancer, vol. 14, no. 3, pp. 185-190, 2011.

[42] F. Gao, X. Ma, A. B. Ostmann, and S. K. Das, "GPR30 activation opposes estrogen-dependent uterine growth via inhibition of stromal ERK1/2 and Estrogen receptor alpha (ER $\alpha)$ phosphorylation signals," Endocrinology, vol. 152, no. 4, pp. 1434-1447, 2011.

[43] E. M. De Francesco, M. Pellegrino, M. F. Santolla et al., "GPER mediates activation of hiflalpha/VEGF signaling by estrogens," Cancer Research, vol. 74, no. 15, pp. 4053-4064, 2014.

[44] A. Vivacqua, R. Lappano, E. M. De Francesco, P. De Marco, and M. Maggiolini, "Multifactorial regulation of GPER expression in cancer cells and cardiomyocytes," Immunology, Endocrine and Metabolic Agents in Medicinal Chemistry, vol. 11, no. 4, pp. 235-242, 2011.

[45] E. A. Ariazi, J. L. Ariazi, F. Cordera, and V. C. Jordan, "Estrogen receptors as therapeutic targets in breast cancer," Current Topics in Medicinal Chemistry, vol. 6, no. 3, pp. 181-202, 2006.

[46] M. Skrzypczak, S. Schüler, C. Lattrich, A. Ignatov, O. Ortmann, and O. Treeck, "G protein-coupled estrogen receptor (GPER) expression in endometrial adenocarcinoma and effect of agonist G-1 on growth of endometrial adenocarcinoma cell lines," Steroids, vol. 78, no. 11, pp. 1087-1091, 2013.

[47] P. B. Tchounwou, B. A. Wilson, A. B. Ishaque, and J. Schneider, "Atrazine potentiation of arsenic trioxide-induced cytotoxicity and gene expression in human liver carcinoma cells (HepG2)," Molecular and Cellular Biochemistry, vol. 222, no. 1-2, pp. 49-59, 2001.

[48] E. R. Prossnitz and M. Barton, "Estrogen biology: new insights into GPER function and clinical opportunities," Molecular and Cellular Endocrinology, vol. 389, no. 1-2, pp. 71-83, 2014.

[49] E. R. Prossnitz and M. Maggiolini, "Mechanisms of estrogen signaling and gene expression via GPR30," Molecular and Cellular Endocrinology, vol. 308, no. 1-2, pp. 32-38, 2009.

[50] H. Buteau-Lozano, G. Velasco, M. Cristofari, P. Balaguer, and M. Perrot-Applanat, "Xenoestrogens modulate vascular endothelial growth factor secretion in breast cancer cells through an estrogen receptor-dependent mechanism," Journal of Endocrinology, vol. 196, no. 2, pp. 399-412, 2008.

[51] H. O. Smith, H. Arias-Pulido, D. Y. Kuo et al., "GPR30 predicts poor survival for ovarian cancer," Gynecologic Oncology, vol. 114, no. 3, pp. 465-471, 2009.

[52] H. O. Smith, K. K. Leslie, M. Singh et al., "GPR30: a novel indicator of poor survival for endometrial carcinoma," American Journal of Obstetrics \& Gynecology, vol. 196, no. 4, pp. 386.el386.el1, 2007.

[53] E. J. Filardo, C. T. Graeber, J. A. Quinn et al., "Distribution of GPR30, a seven membrane-spanning estrogen receptor, in primary breast cancer and its association with clinicopathologic determinants of tumor progression," Clinical Cancer Research, vol. 12, no. 21, pp. 6359-6366, 2006.

[54] E. R. Levin, "Integration of the extranuclear and nuclear actions of estrogen," Molecular Endocrinology, vol. 19, no. 8, pp. 19511959, 2005.
[55] G. Castoria, A. Migliaccio, A. Bilancio et al., "PI3-kinase in concert with Src promotes the S-phase entry of oestradiolstimulated MCF-7 cells," The EMBO Journal, vol. 20, no. 21, pp. 6050-6059, 2001.

[56] G. Castoria, A. Migliaccio, M. Di Domenico et al., "Role of atypical protein kinase $\mathrm{C}$ in estradiol-triggered G1/S progression of MCF-7 cells," Molecular and Cellular Biology, vol. 24, no. 17, pp. 7643-7653, 2004.

[57] R. J. Santen, R. X. Song, R. McPherson et al., "The role of mitogen-activated protein (MAP) kinase in breast cancer," Journal of Steroid Biochemistry and Molecular Biology, vol. 80, no. 2, pp. 239-256, 2002.

[58] R. X.-D. Song, R. A. McPherson, L. Adam et al., "Linkage of rapid estrogen action to MAPK activation by $\mathrm{ER} \alpha$-Shc association and Shc pathway activation," Molecular Endocrinology, vol. 16, no. 1, pp. 116-127, 2002.

[59] Z. Zhang, B. Maier, R. J. Santen, and R. X.-D. Song, "Membrane association of estrogen receptor a mediates estrogen effect on MAPK activation," Biochemical and Biophysical Research Communications, vol. 294, no. 5, pp. 926-933, 2002.

[60] M. B. Martin, M. Saceda, and R. K. Lindsey, "Regulation of estrogen receptor expression in breast cancer," Advances in Experimental Medicine and Biology, vol. 330, pp. 143-153, 1993.

[61] M. Borrás, L. Hardy, F. Lempereur et al., "Estradiol-induced down-regulation of estrogen receptor. Effect of various modulators of protein synthesis and expression," Journal of Steroid Biochemistry and Molecular Biology, vol. 48, no. 4, pp. 325-336, 1994.

[62] J. J. Pink and V. C. Jordan, "Models of estrogen receptor regulation by estrogens and antiestrogens in breast cancer cell lines," Cancer Research, vol. 56, no. 10, pp. 2321-2330, 1996.

[63] E. A. Vladusic, A. E. Hornby, F. K. Guerra-Vladusic, J. Lakins, and R. Lupu, "Expression and regulation of estrogen receptor beta in human breast tumors and cell lines," Oncology Reports, vol. 7, no. 1, pp. 157-167, 2000. 

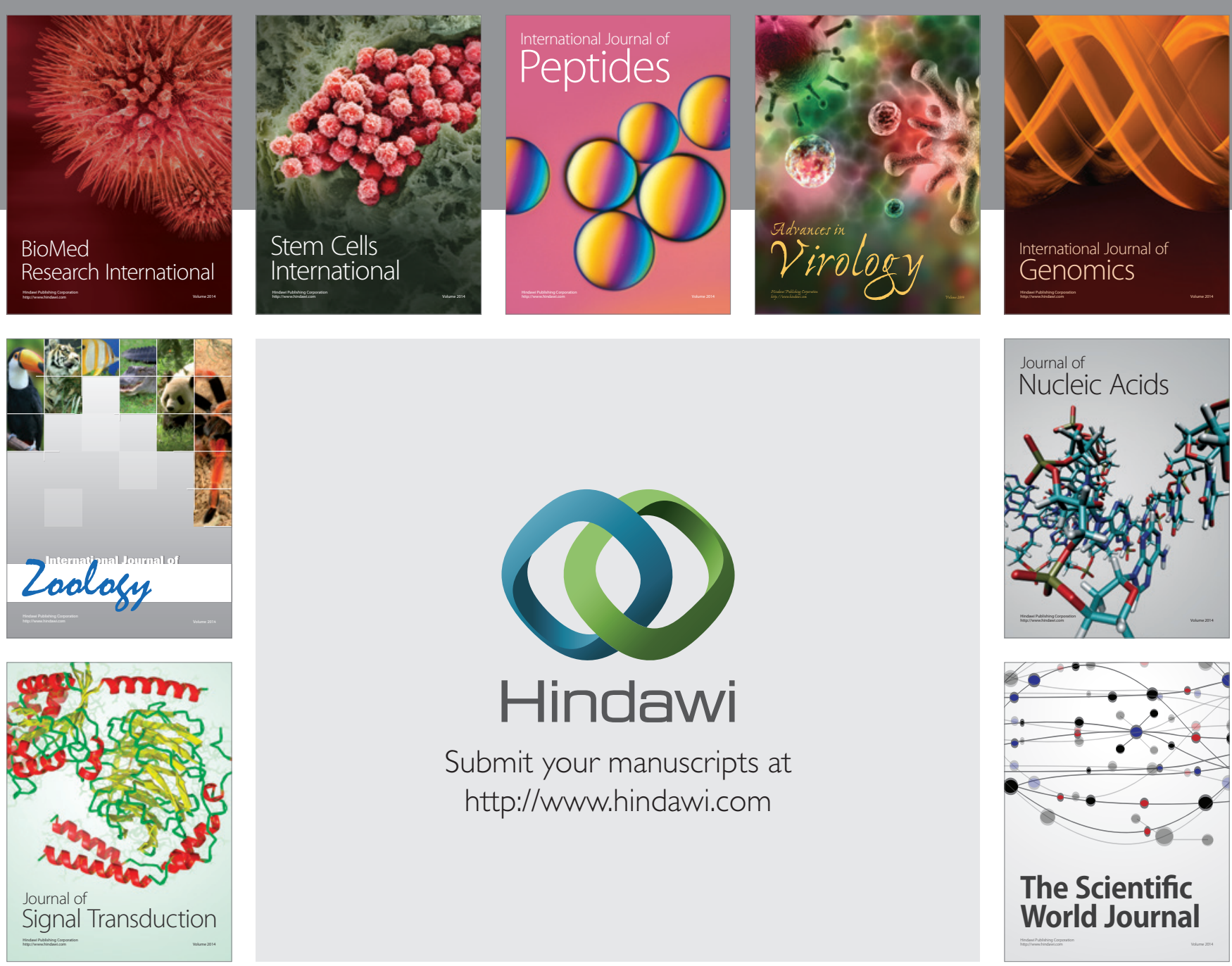

Submit your manuscripts at

http://www.hindawi.com
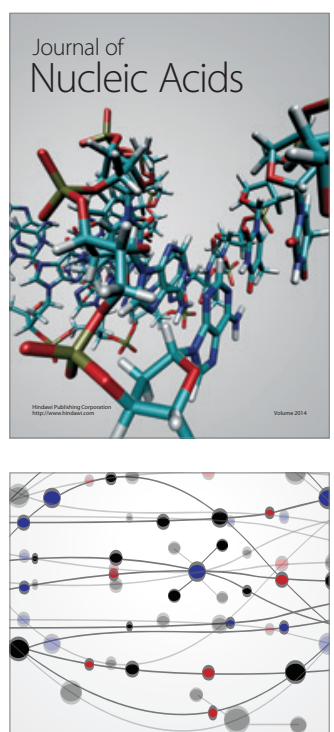

The Scientific World Journal
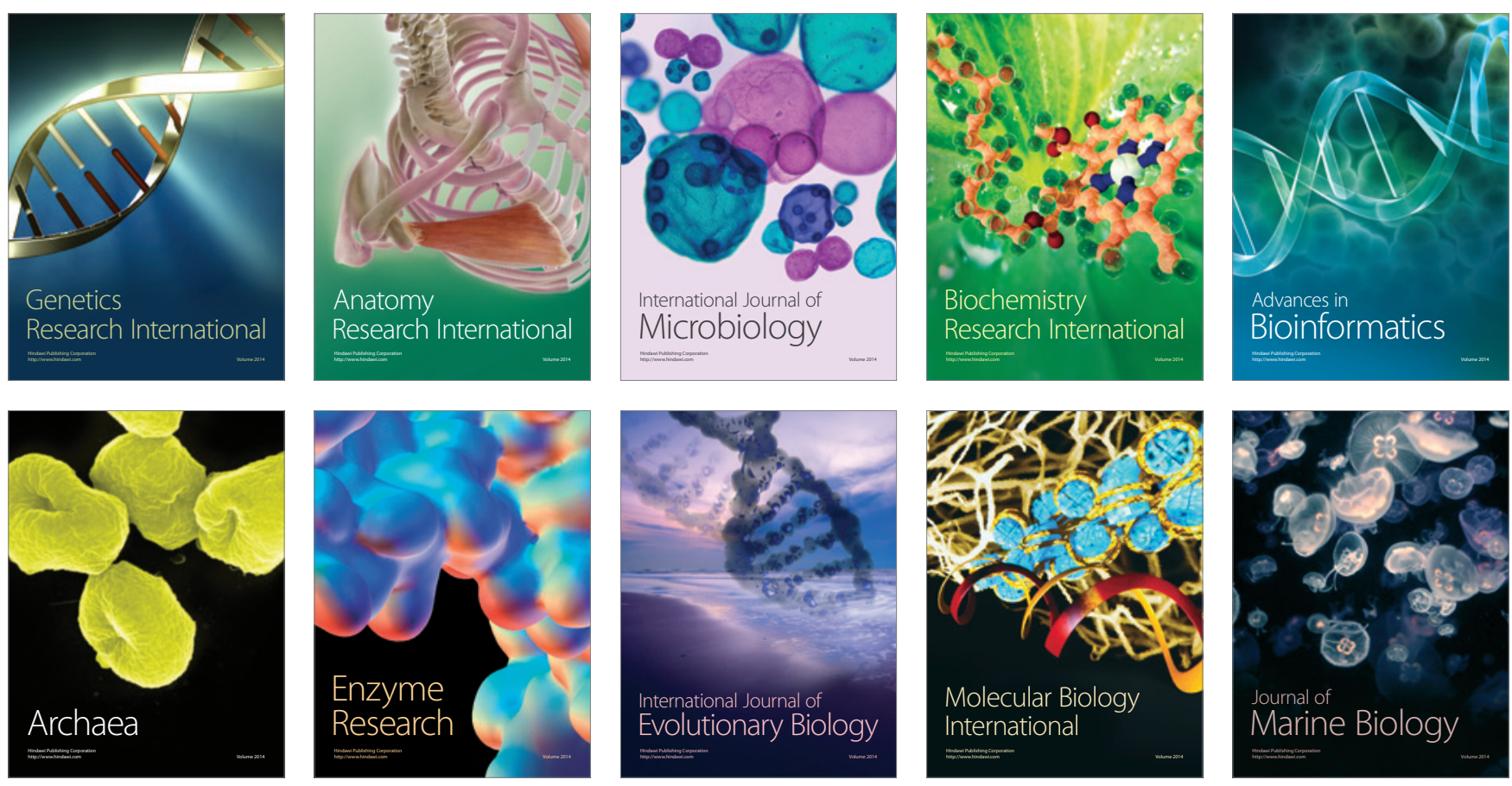